\title{
Upaya Komunikasi Pemasaran Terpadu Televisi Lokal Melalui Budaya Lokal
}

\author{
Umaimah Wahid ${ }^{1}$ dan Menati Fajar Rizki² \\ ${ }^{1,2}$ Universitas Budi Luhur
}

\begin{abstract}
ABSTRAK
Televisi lokal memerlukan upaya khusus untuk memperkenalkan brandnya. Brand televisi lokal, I Channel Bandung, menggunakan kekayaan budaya lokal untuk meningkatkan kesadaran penonton. Tujuan penelitian ini adalah untuk mengetahui proses peningkatan brand awareness televisi I Channel Bandung melalui acara budaya lokal "Sampurasun Cepot" dengan menggunakan teori komunikasi pemasaran Integrated Marketing Communication (IMC). Penelitian ini juga melihat tingkat brand awareness I Channel Bandung yang dicapai setelah menggunakan program acara "Sampurasun Cepot". Teori yang digunakan penelitian ini, Integrated marketing communication Tuckwell serta teori tingkatan brand awareness dari Aaker. Penelitian berfokus pada implementasi enam elemen penting IMC yang dilakukan untuk meningkatkan brand I Channel Bandung yaitu melalui advertising, sales promotion, direct marketing, public relations, personal selling, dan event and sponsorship. Penelitian menggunakan metode studi kasus dengan pendekatan kualitatif intrinsik dan paradigma konstruktivis. Hasil penelitian ini menunjukkan bahwa komunikasi pemasaran terpadu dapat dikaitkan dengan penggunaan satu program acara budaya untuk meningkatkan brand awareness perusahaan. Penggunaan program acara wayang golek "Sampurasun Cepot" berhasil menarik penonton menjadi lebih sadar akan kehadiran televisi lokal ini. Brand awareness I Channel Bandung berhasil meningkat dan mencapai level brand recall di benak penonton. Namun faktanya, televisi lokal I Channel Bandung membutuhkan upaya marketing yang serius dan meningkat pemanfaatan media sosial sebagai alat promosi dan menambah kualitas dan jumlah sumber daya manusia.
\end{abstract}

Kata-kata Kunci: Budaya lokal; i channel bandung; komunikasi pemasaran terpadu; merek; televisi lokal

\section{Integrated Marketing Communication Local Television I Channel Bandung Through Local Culture}

\begin{abstract}
Local television requires special efforts to introduce its brand. Local television brand, I Channel Bandung, uses the richness of local culture to gain audience awareness. The purpose of this research was to study the process of developing brand awareness of I Channel Bandung through "Sampurasun Cepot" local cultural television program using the marketing communication theory of Integrated Marketing Communication (IMC). This study also looked at the level of awareness of the I Channel Bandung brand which was achieved after using the "Sampurasun Cepot" program. The theory used in this research is Tuckwell's integrated marketing communication and Aaker's brand awareness theory. The research focuses on implementing the six important elements of IMC that are carried out to enhance the I Channel Bandung brand through advertising, sales promotion, direct marketing, public relations, personal selling, and event and sponsorship. This research uses case study method using intrinsic qualitative and constructivist paradigms. The results of this research indicate that marketing communication can be associated with cultural program to increase awareness of the company's brand. The use of puppet show "Sampurasun Cepot" is managed to attract the audience became more aware of the presence of this local television. The I Channel Bandung brand awareness was successfully increased and reached the highest level of brand recall in the minds of the audience. But in fact, local television I Channel Bandung need to take a serious effort in marketing and improve social media utilization as a promotional tool and increase the quality of human resources.
\end{abstract}

Keywords: Brand; i channel bandung; integrated marketing communication; local culture; local television

Korespondensi: Dr. Umaimah Wahid. Universitas Budi Luhur. Jl. Ciledug Raya, Kota Jakarta Selatan 12260.Email: umaimah.wahid@budiluhur.ac.id 


\section{PENDAHULUAN}

Kehadiran televisi lokal di Indonesia mengangkat berbagai unsur -unsur kebudayaan daerah setempat. Semangat televisi lokal memanfaatkan nilai-nilai kebudayaan daerah menjadikan televisi lokal mempunyai peran dalam melestarikan kebudayaan dan konten pendidikan, bukan hanya hiburan semata. Hal tersebut berdasarkan Pasal 36 ayat $1 \mathrm{UU}$ Nomor 32 tahun 2002 tentang Penyiaran yang menyatakanbahwa"Isisiaranwajibmengandung informasi, pendidikan, hiburan, dan manfaat untuk pembentukan intelektualitas, watak, moral, kemajuan, kekuatan bangsa, menjaga persatuan dan kesatuan, serta mengamalkan nilai-nilai agama dan budaya Indonesia". Oleh karenanya, televisi lokal merupakan media yang dipercaya dapat menjadi alternatif penyebaran informasi terutama informasi budaya lokal di tengah gempuran budaya popular yang diusung televisi-televisi swasta nasional. Televisi lokal diharapkan menawarkan alternatif tayangan yang berpihak kepada kekayaan nilai-nilai budaya lokal/daerah, sekaligus sebagai media yang memberikan informasi mengenai pembangunan daerah atau sosialisasi programprogram pemerintah daerah.

Berdasarkan Peraturan Pemerintah Republik Indonesia Nomor 11 Tahun 2005 Tentang Penyelenggaraan Penyiaran Publik Pasal 4:

RRI, TVRI, dan Lembaga Penyiaran Publik Lokal bertujuan menyajikan program siaran yang mendorong terwujudnya sikap mental masyarakat yang beriman, bertakwa, cerdas, memperkukuh integrasi nasional dalam rangka membangun masyarakat mandiri, demokratis, adil, dan sejahtera, serta menjaga citra positif bangsa.

Salah satu televisi lokal yang memanfaatkan kekayaan budaya lokal adalah I Channel Bandung. Stasiun IChannel Bandungmerupakan salah satu televisi lokal dari 11 (sebelas) televisi lokal lainnya di Bandung (PPID Bandung, 2017). Selain I Channel Bandung, Bandung terdapatr 10 stasiun televisi lokal lainnya yaitu TVRI Jawa Barat, BCTV Bandung, iNews Bandung, Garuda TV, I Channel Bandung, Parijz van Java TV (PJTV), 7NET. Bandung, Kompas, CT Channel, Bandung TV dan MQTV (Manajemen Qalbu TV) (PPID Bandung, 2017)
Stasiun I Channel Bandung menggunakan kebudayaan lokal untuk membentuk dan memperkuat merek di tengah masyarakat. Merek yang dikenal dan kuat dapat berimplikasi terhadap pendapatan atau nilai ekonomi. Semakin terkenal sebuah program acara memberi peluang banyaknya iklan atau kerja sama yang menguntungkan bagi pengelola stasiun televisi. Penggunaan budaya lokal I Channel Bandung masih relatif baru dalam memanfaatkan konsep budaya lokal, yaitu baru dua atau tiga tahun belakangan. Sebelumnya, program acara dikemas dengan konsep berani dan modern dengan khalayak sasarannya adalah anak-anak muda kota Bandung. Namun, sangat disayangkan televisi ini belum dikenal oleh banyak khalayak. Artinya, I Channel belum berhasil membangun merek yang dikenal kuat oleh khalayak kota Bandung. Kondisi tersebut berimplikasi terhadap rendahnya jumlah penonton dan iklan yang diterima. Salah satu program yang cukup berhasil adalah Program "Sampurasun Cepot".

Keberhasilan tersebut memperkuat eksistensi merek dan mampu membangun kesadaran masyarakat terhadap stasiun televisi lokal I Channel Bandung sebagai salah satu televisi yang mengusung kebudayaan lokal. Program "Sampurasun Cepot" berhasil menarik khalayak karena mereka menggunakan tokoh legenda Sunda pada wayang golek yaitu 'Cepot' yang masih menjadi ikon Jawa Barat dan Bandung khususnya sehingga kecenderungan masyarakat memilih menonton I Channel Bandung terutama program acara "Sampurasun Cepot".

Industri televisi khususnya televisi lokal sangat perlu membangun kekuatan merek di tengah maraknya persaingan. Hal ini agar masyarakat dapat dengan mudah mencirikan secara jelas satu televisi lokal dengan lokal lainnya. Shimp mengungkapkan bahwa merek mempunyai peran penting dengan menjadi pembeda antara jasa atau produk yang ditawarkan suatu perusahaan dengan merekmerek saingannya (Shimp, 2000). Sementara itu, menurut Rangkuti, kecenderungan perkembangan perang pemasaran di masa mendatang akan menjadi perang antar merek, penting untuk ditingkatkan pada masyarakat agar sebuah produk dapat terus berjalan dan berkembang (Rangkuti, 2004).

Peningkatan kesadaran merek yang 
diperlukan oleh sebuah produk dapat dilakukan dengan menggunakan komunikasi pemasaran terpadu. Komunikasi adalah alat yang sangat penting dalam proses pembentukan sebuah merek di kalangan masyarakat/konsumen. Program komunikasi pemasaran yang dilakukan sebaiknya tidak dilakukan secara terpisah, namun akan lebih baik secara bersama-sama. (Keke, 2015) Komunikasi adalah alat unik yang digunakan pemasar untuk mempersuasi konsumen agar bertindak sesuai dengan harapan perusahaan dan merupakan usaha yang terorganisir untuk mempengaruhi dan meyakinkan pelanggan agar membuat pilihan yang tepat sesuai dengan keinginan pemasar serta sejalan dengan kebutuhan pelanggan.

Televisi Lokal I Channel Bandung menggunakan program acara "Sampurasun Cepot" untuk melakukan branding. Aktivitas branding tersebut terdiri dilakukan melalui berbagai bentuk yaitu promosi, iklan, personal selling, direct marketing. Salah satu strategi promosi yang dilakukan adalah penggunaan bahasa Sunda dalam humor-humor yang khas. Kemasan program menggunakan kekayaan budaya lokal ini diharapkan disukai khalayak atau penonton, sekaligus sebagai upaya peningkatan kesadaran merek I Channel Bandung. Strategi menggunakan humor dapat menjadi salah satu strategi komunikasi pemasaran yang dapat diterapkan untuk meningkatkan kesadaran merek. Berdasarkan hasil penelitian Arisandi menunjukkan bahwa penggunaan humor appeals (pendekatan humor) pada iklan televisi berpengaruh positif dan signifikan terhadap brand awareness suatu produk. Hal ini dapat diartikan bahwa semakin lucu atau semakin tinggi unsur humor dalam suatu iklan maka brand awareness terhadap produk tersebut juga akan semakin meningkat. (Arisandi, 2017).

Berdasarkan pertimbangan tersebut, televisi lokal I Channel Bandung menyadari peran penting kesadaran merek untuk mempertahankan dan memenangkan persaingan. Salah satu upaya yang dilakukan adalah membangun kesadaran merek I Channel menggunakan program kekayaan budaya lokal yaitu Wayang Golek dengan lakon 'Cepot'. Penggunaan kekayaan budaya lokal tersebut diharapkan dapat mempermudah penerimaan masyarakat sehingga dapat menjadi kekuatan bagi I Channel Bandung. Dalam konteks komunikasi pemasaran terpadu, konsistensi pesan yang digunakan juga sangat penting. Saleh menyatakan bahwa pesan yang konsisten akan membangun keyakinan konsumen pada merek karena konsumen membutuhkan lebih dari satu kali penyampaian informasi agar konsumen terpersuasi oleh pesan yang disampaikan. (Mahayuni, Purnawan dan Cahyani, 2017).

Fenomena tersebut menarik untuk diteliti karena kecenderungan industri televisi lebih banyak menggunakan program-program dengan genre kekinian di bandingkan yang memanfaatkan kekayaan kebudayaan lokal. Namun sebaliknya, televisi lokal I Channel Bandung justru memilih secara serius memanfaatkan kekayaan budaya lokal, Wayang Golek sebagai program unggulan membangun dan meningkatkan kesadaran merek. Nampaknya strategi tersebut justru menjadi salah satu kekuatan I Channel Bandung. Berdasarkan latar belakang telah dipaparkan, maka fokus masalah penelitian ini adalah Bagaimana proses penggunaan penggunaan komunikasi pemasaran terpadu televisi lokal I Channel Bandung dalam meningkat kesadaran merek melalui local culture pada acara wayang golek "Sampurasun Cepot”?.

Penelitian ini menggunakan Teori Komunikasi Pemasaran Terpadu (Integrated Marketing Communicatio). Tuckwell menyatakan bahwa Integrated Marketing Communication (IMC) atau komunikasi pemasaran terpadu merupakan sebuah kordinasi dari semua bentuk komunikasi pemasaran yang dilakukan melalui sebuah program terpadu guna memaksimalkan dampak target pada khalayak (Tuckwell 2008). Definisi tersebut menekankan pada komunikasi pemasaran terpadu yang memanfaatkan semua bentuk promosi untuk menciptakan hasil yang maksimum. Integrated Marketing Communication (IMC) muncul sebagai alat yang memandu praktisi pemasaran dalam mengembangkan dan melaksanakan komunikasi pemasaran yang lebih konsisten dan efektif (Rismayanti, 2017).

Lebih lanjut Tuckwell juga menjelaskan bahwa terdapat peranan strategis dari berbagai elemen komunikasi pemasaran (Tuckwell, 2008). Elemen-elemen yang dimaksud adalah (1) Advertising, merupakan bentuk persuasif dari Teori Komunikasi Pemasaran Terpadu (IMC) yang dirancang untuk menstimulasi tanggapan positif dari target pasar yang telah di 
definisikan. Advertising terdiri dari komunikasi massa melalui media cetak, media elektronik, dan media lain (billboards, Internet, dan lain-lain), (2) Direct marketing, merupakan pengirim pesan kepada target khalayak secara langsung baik surat langsung, telepon interaktif melalui televisi, atau telemarketing, (3) Sales promotion, merupakan promosi penjualan yang melibatkan intensif khusus untuk merangsang reaksi langsung dari konsumen dan distributor, (4) Personal selling, merupakan penjualan pribadi yang melibatkan pesan pribadi dari penjual kepada pembeli. (5) Public relations, merupakan keseluruhan komunikasi yang terencana, baik itu ke dalam maupun ke luar, antara suatu perusahaan dengan semua khalayaknya dalam rangka mencapai tujuantujuan spesifik, dan (6) Event Marketing and Sponsorship merupakan dua hal yang berbeda. Event melibatkan perencanaan, pengorganisasian, dan marketing sebagai event yang terintegrasi dari kegiatan komunikasi lain. Sementara sponsorship merupakan sebuah perusahaan yang menyediakan anggaran untuk mengadakan event dengan tujuan akhir berupa promosi dari perusahaan atau merek itu sendiri.

Kotler menjelaskan bahwa aktivitas IMC merupakan perpaduan spesifik dari lima aktivitas komunikasi pemasaran yang paling sering digunakan perusahaan, yaitu advertising, personal selling, sales promotion, public relations, dan direct marketing (Kotler, 2008). Don Schultz menjelaskan bahwa IMC merupakan proses pengelolaan semua sumber informasi tentang produk/jasa yang ditujukan kepada konsumen atau calon konsumen yang terkena perilaku konsumen dengan tujuan untuk meningkatkan penjualan dan mempertahankan loyalitas konsumen (Anugrah, 2014). IMC dapat membantu perusahaan dalam membuat pesan yang terkoordinasi secara konsisten di berbagai saluran komunikasi sehingga sangat penting dimanfaatkan sebagai "senjata" perusahaan dalam menghadapi berbagai persaingan di dunia bisnis (Rismayanti, 2017).

Lebih lanjut, Oktora menjelaskan menjelaskan terkait penggunaan intregrated marketing communication dalam pemasaran produk bahwa konsep komunikasi pemasaran pun menjadi aplikatif bagi PT Pindad untuk membangun dan meningkatkan kepercayaan negara-negara tujuan PT Pindad untuk semakin mempercayai kualitas Alutsista melalui implementasi pemasarannya melalui konsep Integrated marketing communication (IMC) atau Komunikasi Pemasaran Terpadu (Oktora, 2017). Pemahaman mengenai IMC sendiri menunjukkan bahwa kepentingan komunikasi pemasaran akan berkaitan dengan kemampuan perusahaan dalam mengolah saluran-saluran komunikasi beserta isi pesannya. IMC pun dinilai akan memberikan kontribusi positif bagi PT Pindad. Strategi komunikasi pemasaran terpadu yang digunakan sangat mendukung pemasaran yang dilakukan oleh PT Pindad sehingga memudahkan memasarkan senjata yang diproduksi ke Negara-negara Asia Tenggara. Beberapa bentuk aktivitas IMC yang dilakukan adalah promosi penjualan, hubungan masyarakat dan publisitas, pemasaran langsung, penjualan, dan periklanan. Alasan PT Pindad menggunakan IMC utamanya karena penerapan konsep $\mathrm{G}$ to $\mathrm{G}$ yang mengedepankan lobi-lobi di tingkat pemerintah serta hubungan bilateral dapat mendukung seluruh kegiatan pemasarannya.

Teori lainnya yang digunakan adalah Teori Kesadaran Merek (Brand awareness). Sebelum menjelaskan mengenai kesadaran mereka, akan dijelaskan pemahaman mengenai merek. Menurut Kotler dan Keller, merek atau brand dapat berbentuk logo, nama, trademark atau gabungan dari keseluruhannya. Berdasarkan definisi tersebut suatu merek memiliki fungsi sebagai pembeda antara produk suatu perusahaan dengan perusahaan lain (Kotler \& Keller, 2008). Penggunaan nama, logo, atau merek dagang sangat penting karena hal tersebut merupakan upaya serius yang dilakukan perusahaan untuk memberitahukan kepada konsumen ciri pembeda merek, dan sekaligus bertujuan untuk memberi pengetahuan serta kesadaran merek perusahaan.

Pengertian merek (brand) menurut David A. Aaker adalah nama dan simbol yang bersifat membedakan (seperti sebuah logo, cap, atau kemasan) dengan maksud, mengidentifikasikan barang dan jasa dari seorang penjual (Ruslan 2010). Sedangkan kesadaran merek (brand awareness) disebut Shimp adalah kemampuan sebuah merek untuk muncul dalam benak konsumen ketika mereka sedang memikirkan kategori produk tertentu dan seberapa mudahnya nama tersebut muncul (Wahid \& Anggun, 2017). Aaker mendefinisikan kesadaran merek sebagai kemampuan dari seseorang yang merupakan 
calon pembeli untuk dapat mengenali atau menyebutkan kembali suatu merek merupakan bagian dari suatu kategori produk., kesadaran merek membutuhkan jangkauan yang kontinum dari perasaan yang tak pasti bahwa merek tertentu dikenal, menjadi sebuah keyakinan bahwa produk tersebut merupakan satu-satunya dalam kelas produk bersangkutan (Aaker 1997).

Kesadaran merek menyampaikan bahwa cara mengetahui pelanggan saat ini dan calon pelanggan terhadap produk dan layanan. Kesadaran merek memainkan peran penting saat membeli produk atau layanan dan mungkin memiliki kontrol pada evaluasi risiko yang dirasakan konsumen dan tingkat keyakinan mereka tentang keputusan pembelian karena kesadaran dengan merek dan keunikannya. (Malik, dkk., 2013).

Disebut pula oleh Gustafson bahwa kesadaran merek adalah bersifat probabilitas, konsumen mengetahui ketersediaan dan aksesibilitas produk dan layanan perusahaan (Malik, dkk., 2013). Menurut Aaker, tingkat kesadaran merek adalah sebagai berikut: (1) Unaware of Brand (tidak menyadari merek), yaitu tingkat yang paling rendah dari piramida brand awareness di mana konsumen tidak menyadari akan adanya suatu merek, (2) Brand Recognition (Pengenalan Merek), yaitu tahapan di mana konsumen mengenal merek yaitu tingkat kesadaran konsumen terhadap suatu merek diukur dengan memberikan bantuan seperti ciriciri suatu produk, (3) Brand recall (Pengingatan Kembali Merek), yaitu pengingatan kembali suatu merek yang dicerminkan dengan merek lain yang diingat oleh responden setelah menyebutkan merek yang pertama, 4), dan Top of Mind (Puncak Pikiran), yaitu merek yang pertama kali diingat oleh konsumen atau pertama kali disebut ketika konsumen ketika di tanya tentang suatu produk tertentu. Tingkatan ini menggunakan single respond question yang artinya responden hanya boleh memberikan satu jawaban untuk pertanyaan mengenai hal ini (Putra \& Idris, 2011).

Kesadaran merek dianggap sebagai metrik yang sangat penting untuk merek baru, sedangkan pengetahuan merek dan pendapat merek menjadi relevan untuk merek yang mapan. Tetapi bahkan merek mapan pun menghadapi pembeli kategori baru, di mana kesadaran masih perlu ditetapkan. Oleh karena itu, kesadaran relevan untuk semua merek, baik besar atau kecil dalam pangsa pasar (Romaniuk, Wight \& Faulkner, 2017).

Adapun konsep yang digunakan adalah budaya lokal (local culture). Ada beberapa pengertian budaya menurut beberapa ahli, salah satu di antaranya adalah Koentjaraningrat. Menurut Koentjaraningrat, kebudayaan dengan kata dasar budaya berasal dari bahasa Sansakerta 'buddhayah', yaitu bentuk jamak dari buddhi yang berarti 'budi' atau 'akal'. Jadi, Koentjaraningrat mendefinisikan budaya sebagai 'daya budi' yang berupa cipta, karsa dan rasa, sedangkan kebudayaan adalah hasil dari cipta, karsa, dan rasa itu (Koentjaraningrat, 2000) .

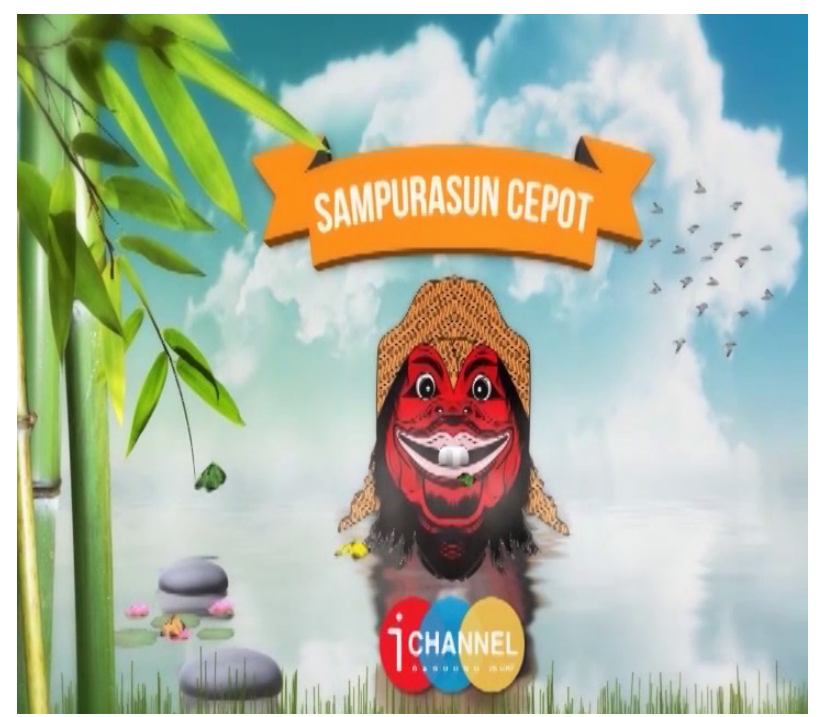

Sumber: I Channel, 2016

\section{Gambar 1 Program Acara 'Sampurasun Cepot'}

Sedangkan Tylor mengemukakan bahwa "kebudayaan sebagai kumpulan yang kompleks dari pengetahuan, kepercayaan, seni, hukum, moral, adat istiadat dan setiap kemampuan lain atau kebiasaan yang diperoleh oleh manusia sebagai anggota masyarakat", meskipun sebelumnya, Tylor sendiri pernah mengatakan bahwa penggunaan istilah kebudayaan sangat membingungkan dan kontradiktif(bertentangan) (Liliweri, 2002). Ahli antropologi A.L.Kroeber dan J.J. Honigmann juga pernah menganjurkan untuk membedakan secara tajam wujud kebudayaan, yaitu (1) ideas, (2) activities, dan (3) artifact (Koentjaranigrat, 2000).

Menurut Liliweri kebudayaan merupakan pandangan hidup dari sekelompok orang dalam bentuk perilaku, kepercayaan, nilai, dan simbol-simbol yang mereka terima tanpa sadar 
yang semuanya diwariskan melalui proses komunikasi dari satu generasi ke generasi berikutnya (Liliweri, 2002). Lebih lanjut, Taylor mendefinisikan budaya tersusun oleh kategori-kategori kesamaan gejala umum yang disebut adat istiadat yang mencakup teknologi, pengetahuan, kepercayaan, kesenian, moral, hukum, estetika, relaksasi, kemampuankemampuan tertentu yang dimiliki, dan kebiasaan-kebiasaan yang diperoleh dari hasil interaksi sebagai anggota masyarakat lain, kebudayaan mencakup semua aspek yang didapatkan dan dipelajari oleh manusia dalam konstruksi sosial masyarakat (Liliweri, 2002).

Televisi Lokal muncul sebagai upaya positif untuk menyeimbang dampak dari televisi swasta yang menguasai penyiaran di Indonesia dan kondisi tersebut dikhawatirkan dapat merugikan masyarakat dan budaya lokal Indonesia. Menurut Morissan televisi lokal merupakan salah satu stasiun televisi di Indonesia yang berbasis kedaerahan yang disiarkan melalui satelit dan kabel yang menggunakan otonomi daerah untuk pembiayaannya (Morissan, 2005). Televisi lokal sangat berperan dalam menghidupkan budaya dan kesenian daerah sekaligus mendapatkan target khalayak mereka. Di Indonesia, strategi untuk mengangkat budaya lokal masyarakat atau nilai etnik terbukti berhasil menjaring banyak.

Televisi lokal dipercaya dapat menjadi alternatif tontonan bagi masyarakat yang lebih mengedepankan kearifan budaya lokal serta diharapkan dapat mengangkat budaya dan kearifan lokal (local wisdom) yang hidup dan berkembang di masyarakat. Hal tersebut dapat membantu proses pembelajaran dan penanaman nilai-nilai positif budaya setempat. Televisi lokal diharapkan memberi nuansa baru dalam mengisi ruang publik, memberikan alternatif pilihan informasi dan hiburan. Pengesahan Undang-Undang No. 32 Tahun 2002 tentang Penyiaran, yang merupakan payung hukum resmi dunia penyiaran di tanah air, membuka peluang bagi berkembangnya televisi-televisi lokal.

Televisi lokal I Channel Bandung menggunakan program berbasis budaya lokal yaitu wayang golek dengan nama acara "Sampurasun Cepot" sebagai strategi komunikasi pemasaran terpadu dalam membangun komunikasi pemasaran terpadu untuk membangun merek mereka agar kuat di tengah masyarakat Bandung. Program acara "Sampurasun Cepot" pertama kali ditayangkan tanggal 6 Januari 2016. Acara ini mengangkat wayang golek sebagai kesenian yang melegenda di Jawa Barat untuk dapat eksis kembali melalui media TV. Acara ini terdiri dari tujuh pemain, satu orang dalang, yaitu dalang Riswa serta enam pemain musik tradisional. Wayang golek sebagai kesenian khas Sunda berfungsi sebagai penyampai pesan dan nasihat-nasihat untuk masyarakat dan dibalut dengan humor. Acara "Sampurasun Cepot" ini merupakan media dari I Channel Bandung untuk meningkatkan brand awareness mereka. Acara wayang golek merupakan acara yang kental akan seni budaya dan memiliki banyak keunggulan dalam menarik perhatian penonton. Keunggulankeunggulan ini terdiri dari penggunaan bahasa Sunda, musik tradisional sebagai pengiring jalannya acara, serta tokoh wayang golek itu sendiri.

I Channel Bandung sebagai salah satu televisi lokal mengalami kesulitan dalam meningkatkan jumlah penonton. Hal tersebut salah satunya adalah disebabkan kompetisi yang tinggi dengan stasiun-stasiun televisi lokal yang terdapat di Kota Bandung. Jumlah penonton karena televisi swasta nasional yang cenderung lebih menarik. Oleh karenanya, pihak marketing berusaha untuk membangun dan meningkatkan brand awareness I Channel Bandung dengan menggunakan nilai-nilai budaya lokal, yaitu dalam bentuk kemasan program yang diberi nama "Sampurasun Cepot". I Channel melakukan berbagai bentuk komunikasi pemasaran terpadu, terutama kegiatan-kegiatan tidak yang membutuhkan biaya tinggi, namun efektif dalam meningkatkan brand awareness stasiun I Channel di tengah khalayak kota bandung.

Upaya pembentukan brand dilakukan dengan memanfaat nilai-nilai budaya Sunda yang dikemas dalam program acara dengan menggunakan bahasa dan isu-isu yang diminati oleh penonton khususnya anak-anak muda. Tujuannya adalah meningkatkan brand awareness I Channel Bandung agar lebih diminati oleh khalayak sehingga menyebabkan peningkatan iklan dan pendapatan. Artinya, nilai-nilai budaya lokal dapat dikemas sedemikian rupa untuk menarik penonton sehingga televisi lokal dapat menjadi sumber informasi yang bermanfaat terutama bagi 
pengembangan nilai-nilai lokal.

\section{METODE PENELITIAN}

Penelitian ini menggunakan pendekatan kualitatif. Menurut Denzin dan Lincoln, penelitian kualitatif memiliki penekanan pada proses dan makna yang tidak dikaji secara ketat atau belum di ukur dari sisi kuantitas, jumlah, intensitas, atau frekuensinya (Denzin \& Lincoln, 2009). Penelitian ini juga menggunakan kedalaman analisis yang dikenal dengan interpretif. Menurut Burel dan Morgan, pendekatan interpretif bersifat subjektif, yaitu berusaha memahami kenyataan sosial apa adanya, kesadaran terlibat, kenyataan sosial dibentuk oleh kesadaran dan tindakan seseorang mencari makna dibalik sesuatu (Sopanah, 2012). Pertimbangan peneliti menggunakan pendekatan interpretif karena kajian yang diteliti menyangkut dimensi kemanusiaan atau lebih pada sisi subyektifitasnya dalam nilai budaya yang ditampilkan melalui program acara Sampurasun Cepot dalam meningkatkan brand awareness I Channel Bandung.
Adapun metode penelitian yang digunakan adalah studi kasus. Studi kasus menurut Daymon \& Holloway merupakan sebuah pengujian intensif menggunakan berbagai sumber bukti yang dibatasi oleh ruang dan waktu (Daymon \& Holloway, 2008) . Kasus yang diangkat dapat berupa sebuah organisasi, sekumpulan orang, komunitas, peristiwa, proses, isu, maupun kampanye. Pada penelitian ini studi kasus yang diangkat adalah mengenai proses peningkatan brand awareness menggunakan budaya lokal di benak penonton I Channel TV Bandung.

Fokus penelitian ini yaitu mengenai proses peningkatan kesadaran merek menggunakan budaya lokal I Channel TV Bandung. Alasan mendasar penulis menggunakan pendekatan studi kasus dalam penelitian ini, yaitu: (1) Kasus yang diangkat bersifat unik. Hal ini bisa dilihat dari fokus penelitian yang ingin melihat nilainilai budaya berperan dalam meningkatkan kesadaran merek pada penonton TV lokal I Channel Bandung. Nilai-nilai budaya tersebut dituangkan melalui acara Sampurasun Cepot dan (2) Kasus yang dipilih mampu menjadi bukti dari teori yang telah dibangun dengan

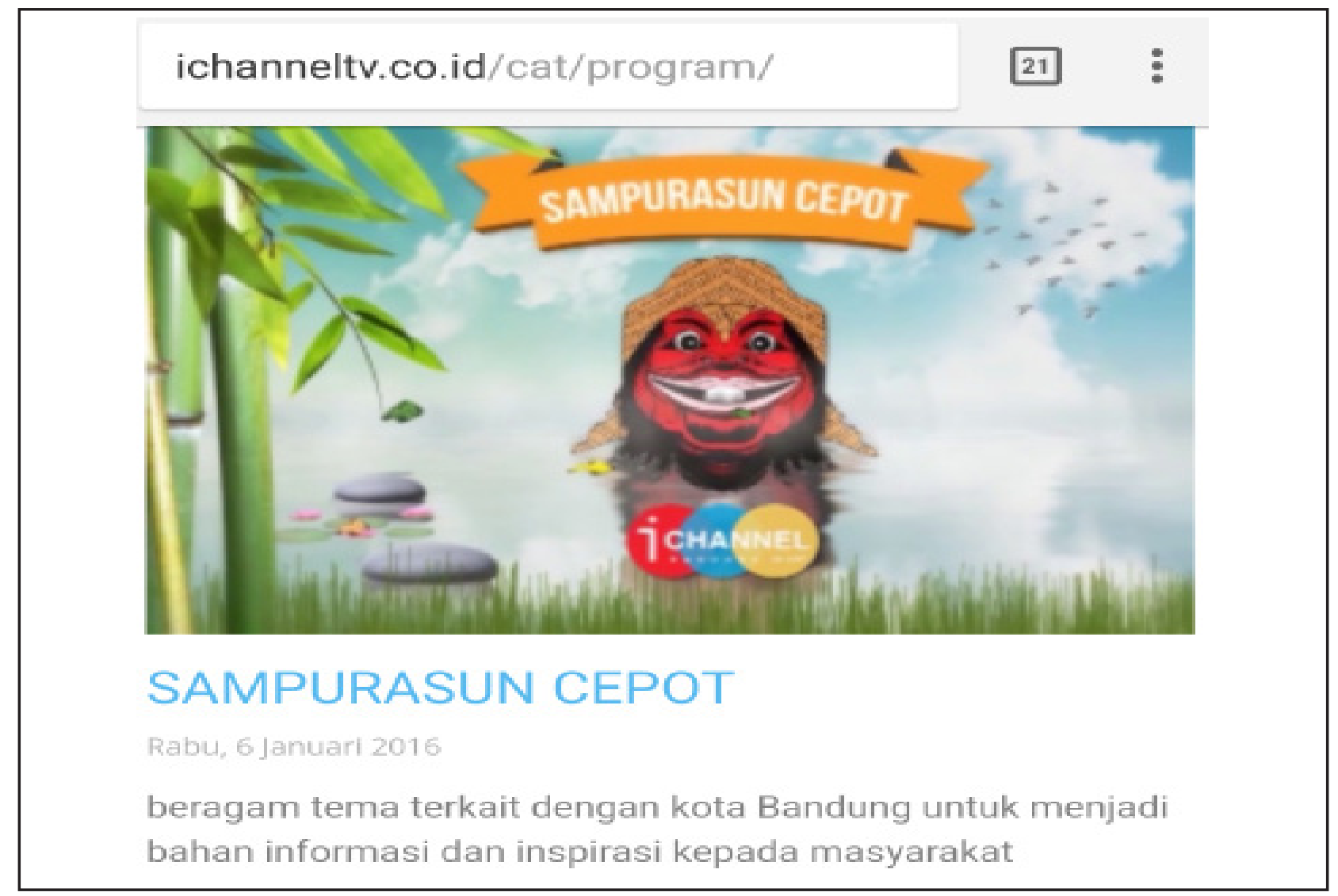

Sumber: Website I Channel Bandung, 2017

Gambar 2 Media Promosi Official Website 
baik. Teori dibangun memiliki proposisi yang jelas serta sesuai dengan kasus tunggal yang dipilih sehingga dapat dipergunakan untuk membuktikan kebenarannya.

Subjek penelitian yang digunakan adalah para pihak atau pelaku yang terlibat pada proses peningkatan brand awareness melalui local culture, yaitu: (1) Ria Rinjani yaitu Kepala Marketing Komunikaksi sebagai key informant, (2) Rori Yamnyo yaitu Produser Acara Sampurasun Cepot, (3) Aulia Khaera Arfah S yaitu Staf Marketing Komunikasi I Channel Bandung, (4) Dalang Riswa yaitu dalang dalam acara "Sampurasun Cepot", (5) Anita Sukama yaitu Siswi SMA Istiqamah Bandung, (6) Alwin Nugraha (Aha) yaitu Siswa SMK 1 Bina Bakti, Bandung, dan (7) Wahyu Wibisana yaitu Mahasiswa Bina Sarana Informatika Bandung.

Data primer dari penelitian ini diperoleh dari hasil (1) wawancara mendalam (in-dept interview) dengan informan untuk mengetahui proses peningkatan brand awareness di benak penonton I Channel Bandung, yang dilakukan selama 4 bulan, (2) observasi non partisipan, yaitu peneliti terjun langsung ke lapangan untuk mengamati proses produksi program acara "Sampurasun Cepot", dan (3) dokumentasi digunakan peneliti untuk mengetahui dokumendokumen serta foto, dan juga rekaman acara Sampurasun Cepot. Lokasi penelitian terletak di Jl. Prof. Dr. Ir. Sutami Komp. Setrasari Mall Blok B4 No. 74 Bandung dan dilakukan selama empat bulan dimulai dari bulan AgustusDesember 2017.

\section{HASIL DAN PEMBAHASAN}

Komunikasi pemasaran terpadu yang dilakukan pihak internal I Channel Bandung untuk menciptakan kesadaran merek di benak masyarakat sesuai dengan pernyataan dari Tuckwell yaitu sebagai berikut: pemasaran langsung (direct marketing), promosi penjualan (sales promotion), iklan (advertising), penjualan tatap muka (personal selling), hubungan masyarakat (public relations), acara dan sponsor (event and sponsopship) (Tuckwell, 2008).

Advertising atau proses penyampaian pesan penawaran mengenai suatu produk, jasa atau ide kepada masyarakat melalui media massa maupun media online mampu memengaruhi masyarakat untuk dapat menggunakan produk atau jasa maupun ide yang ditawarkan.
Salah satu upaya tim marketing dalam mempromosikan acara "Sampurasun Cepot" adalah menyajikan iklan dalam bentuk audiovisual yang ditayangkan berulang-ulang di TV. Tujuannya adalah mengingatkan pemirsa akan acara tersebut. Selain itu, iklan dipilih oleh bagian marketing I Channel Bandung sebagai salah satu strategi komunikasi pemasaran. Seperti yang dikemukakan oleh key informant yaitu:

Untuk iklan dari acara "Sampurasun Cepot" sendiri biasanya diselipkan juga saat tayangan program acara lain, terus iklan tayangan acara juga ada di TV, karena kita kan ada di industri media yah, jadi semua yang dilakukan sebisa mungkin memang yang efektiflah gitu dalam beriklan. Kalau untuk media lain tetep media sosial yang kita gunakan.

Iklan memiliki peranan yang sangat penting dalam memengaruhi pengetahuan masyarakat terhadap pesan atau informasi mengenai program acara wayang golek "Sampurasun Cepot'. Pihak marketing komunikasi I Channel Bandung menyadari bahwa iklan dapat menjadi salah satu bentuk informasi yang dapat meningkatkan kesadaran publik terutama anak muda terhadap stasiun televisi lokal I Channel Bandung. Pandangan ini sebagaimana dikemukakan oleh informan kedua sebagai berikut: "Iklan juga menjadi salah satu strategi marketing dalam upaya kita meningkatkan kesadaran merek kepada masyarakat".

Iklan digunakan oleh I Channel Bandung sebagai cara peningkatan kesadaran merek agar masyarakat dapat mengetahui keberadaan serta mendapat informasi terkait dengan TV lokal ini. Penggunaan media sosial pun menjadi salah satu penunjang dalam pemberian informasi kepada masyarakat, dikarenakan pergeseran budaya yang harus diikuti oleh perusahaan baik produk maupun jasa untuk tetap dapat eksis dan menjangkau masyarakat dengan efisien. Seperti yang diungkapkan oleh key informant mengenai media sosial, yaitu:

Media sosial itu menjadi media yang termudah dan tercepat dalam memberikan informasi ke masyarakat yah. Kita punya media sosial itu ada Twitter, Facebook, Instagram, webnya sendiri juga ada. Jadi ya kita menggunakan media yang terefektif dan terefisien gitu karena kan ibaratnya ini 
perusahaan media massa sampai beriklan di media TV lain.

Kegiatan periklanan off air melalui official website dan unofficial website adalah sebagian yang dipilih oleh I Channel Bandung dalam melakukan periklanan acara "Sampurasun Cepot". Official website atau Situs resmi adalah situs yang dikelola langsung yang dapat diakses oleh masyarakat umum dan selalu di update. Direct marketing digunakan sebagai bentuk strategi komunikasi pemasaran dalam meningkatkan kesadaran merek I Channel Bandung. Adapun beberapa cara yang digunakan dalam direct marketing yaitu surat, telepon, email, media sosial atau tatap muka langsung untuk berdialog pada konsumen yang spesifik atau pada calon konsumen yang menjadi sasaran perusahaan. Sebagaimana dinyatakan oleh Staf Marketing Komunikasi I Channel Bandung di bawah ini:

Kegiatan direct marketing kita itu lakukan di I Channel, biasanya untuk penawaran pasang iklan ya.. biasanya kita kirim surat penawaran gitu, paling email, tapi lebih sering digunakan untuk client, tapi ada kok email khusus kita di I Channel26.official@, gmail.com untuk penonton dan masyarakat umumlah kira-kira gitu ya.
I Channel Bandung mencoba mengemas informasi yang ditujukan kepada calon konsumen dengan mengirimkan email atau surat penawaran langsung. Penawaran pemasangan iklan di stasiun TV biasanya dilakukan oleh marketing dengan memberikan beberapa pilihan acara dan jam tayang dari TV mereka. Acara yang digunakan untuk slot iklan harus memiliki daya tarik tersendiri bagi calon konsumen seperti yang dikatakan oleh key informant, yaitu:

Kita menggunakan media sosial juga untuk mendirect penonton kalau habis syuting "Sampurasun Cepot", kita update di medsos, biar penonton juga tertarik dengan tema baru yang mau kita tayangin gitu.

Direct marketing melalui email ternyata selama ini efektif dan efisien, yang berdampak kepada semakin dikenalnya I Channel Bandung oleh masyarakat terutama khalayan usia muda. Upaya tersebut dilakukan dengan memanfaatkan Internet dan sosial media seperti Instagram, Twitter, dan Facebook.

Kegiatan sales promotion juga dilakukan untuk meningkatkan kesadaran merek perusahaan. Promosi penjualan ini dilakukan oleh divisi marketing mulai dari potongan harga memasang iklan, serta pemberian free peliputan

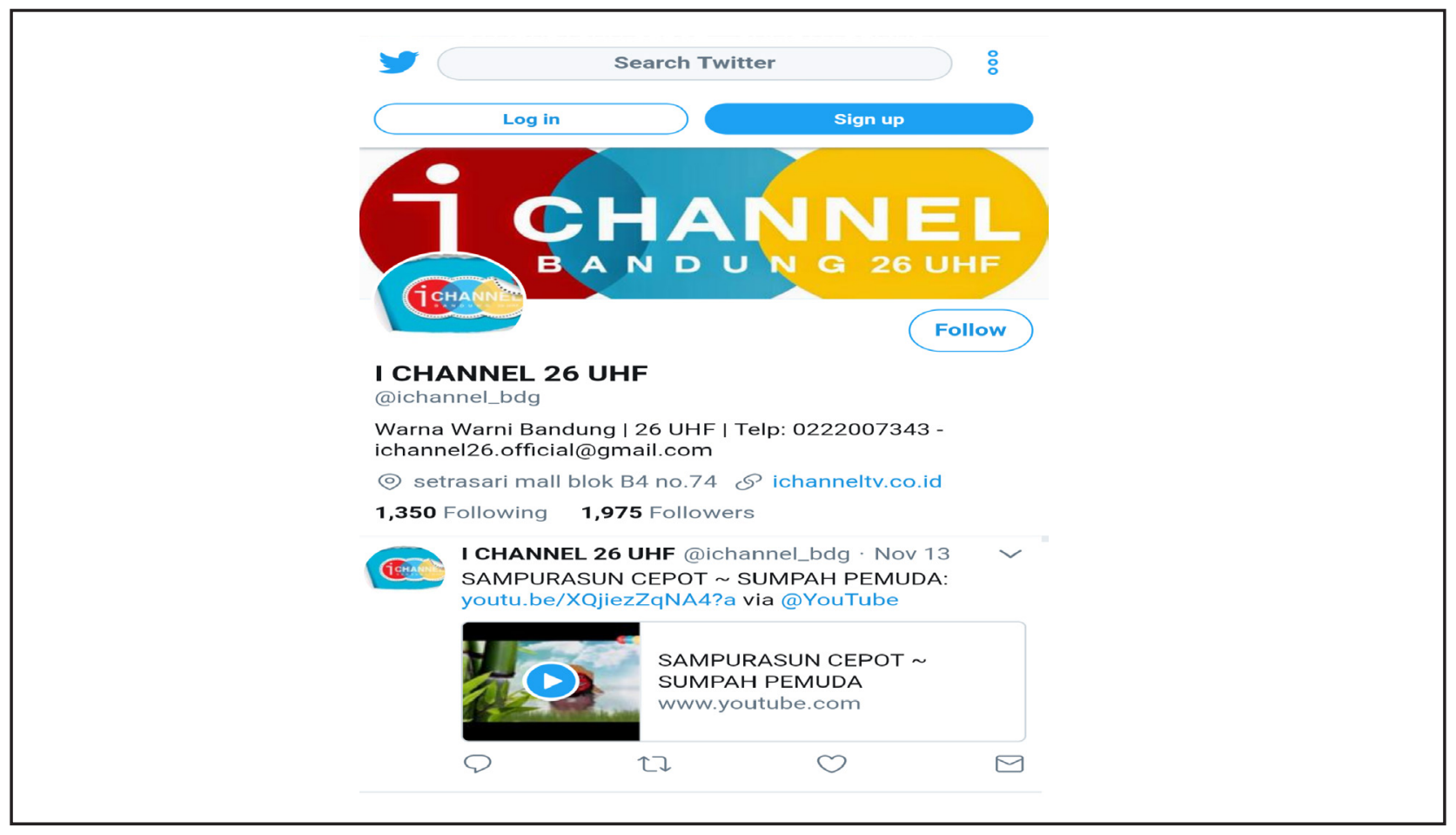

Sumber: Website I Channel Bandung, 2017

Gambar 3 Media Periklanan Unofficial Twitter 
yang nantinya akan berbayar. Dalam memilih strategi sales promotion ini, divisi marketing melakukan beberapa hal, seperti menemui pihak-pihak yang berpeluang beriklan pada acara wayang golek "Sampurasun Cepot". Hal ini sebagaimana dikemukakan oleh key informant, sebagai berikut:

Untuk sales promotion sendiri misalnya nih kalau sudah ketemu client, kita tidak selalu berbicara tentang produk atau pemasangan iklan, Untuk awal biasa saya selalu berikan free payment, tapi untuk selanjutnya akan dikenakan payment dan tarik mereka untuk pasang iklan di I Channel.

Kegiatan promosi lainnya yang dilakukan adalah pemberian merchandise yang diberikan kepada klien maupun penonton. Hal itu bertujuan untuk merangsang pemirsa agar mau menyaksikan acara "Sampurasun Cepot", dan sekaligus upaya tersebut dapat meningkatkan awareness masyarakat terhadap I Channel Bandung.

Di tengah perkembangan sistem marketing online yang merupakan imbas dari tumbuhnya era internet dan sosial media, namun strategi pemasaran komunikasi tatap muka masih digunakan. Tujuan pemanfaatan strategi komunikasi tatap muka adalah agar memungkinkan adanya interaksi dan komunikasi dua arah yang terjadi antara penjual dan konsumen. Menurut Staf Marketing I Channel Bandung:

Penggunaan personal selling ini merupakan salah satu cara yang paling efektif juga dalam peningkatan brand awareness yah, karena kan kita ketemu langsung, ada interaksi di dalam pertemuan itu, banyak percakapan serta kadang malah terjadi diskusi.

Personal selling yang dilakukan oleh Divisi Marketing Komunikasi I Channel Bandungi dapat dikatakan efektif untuk peningkatan brand awareness program wayang golek "Sampurasun Cepot". Selain itu kegiatan ini dapat membangun hubungan antara penjualan dan konsumen, sehingga dapat mengetahui respon langsung dari konsumen.

Hubungan masyarakat atau Public relations merupakan program yang dirancang perusahaan untuk mempromosikan produk-produk khusus atau program yang dilaksanakan guna meningkatkan kesadaran merek perusahaan I Channel Bandung sebagai televisi lokal melalui pemanfataan kebudayaan lokal wayang golek dalam program acara "Sampurasun Cepot". Berdasarkan wawancara key informant diketahui bahwa kegiatan public relations dilakukan untuk membangun dan memelihara hubungan baik dengan masyarakat atau konsumen. Berikut hasil wawancaranya:

Menjalani kegiatan PR itu biasa saya lakukan sekalian kalau ketemu komunitas, atau client. Nah sekarang sudah mulai dengan kegiatan media partner, yang tujuannya untuk publisitas. Beberapa kampus terkenal seperti ITB, UNPAD sudah kerja sama dengan kita. Sekarang ini sudah banyak kampus yang meminta kami untuk menjadi media partner mereka. Ada juga SMA 2 Bandung, itu SMA favorit di Bandung.

Gambar 4 dan gambar 5 merupakan gambar dari poster beberapa acara yang digunakan oleh I Channel Bandung dalam usahanya menjadi media partner untuk mempublikasikan perusahaan. Dalam upaya memperkenalkan, memelihara dan menegaskan kekuatan sebuah merek baru, maka kegiatan event marketing dan sponsorship dapat digunakan agar merek hadir di lokasi-lokasi kegiatan dan diketahui oleh khalayak/konsumen. Event marketing dan sponsorship bertujuan mendapatkan perhatian dari masyarakat yang berujung pada tertanamnya kesadaran merek di benak masyarakat. Namun, televisi lokal I Channel Bandung tidak melakukan kegiatan strategi komunikasi event and sponsorship karena membutuhkan pembiayaan yang relevan cukup besar. Hal tersebut sebagaimana disampaikan oleh informan ke tiga dari I Channel Bandung, yaitu:

Untuk sponsorship di I Channel ini memang belum dilakukan, karena kita kan TV lokal ya, sebisa mungkin menekan budget untuk melakukan kegiatan pemasaran dan peningkatan brand awareness perusahaan. Kalau untuk event nya sendiri ngga ada ya, biasa itu kita lakukan bersamaan dengan program siaran.

Event dan sponsorship membutuhkan budget yang tidak sedikit. Untuk ukuran TV lokal, kurang memungkinkan melakukan 


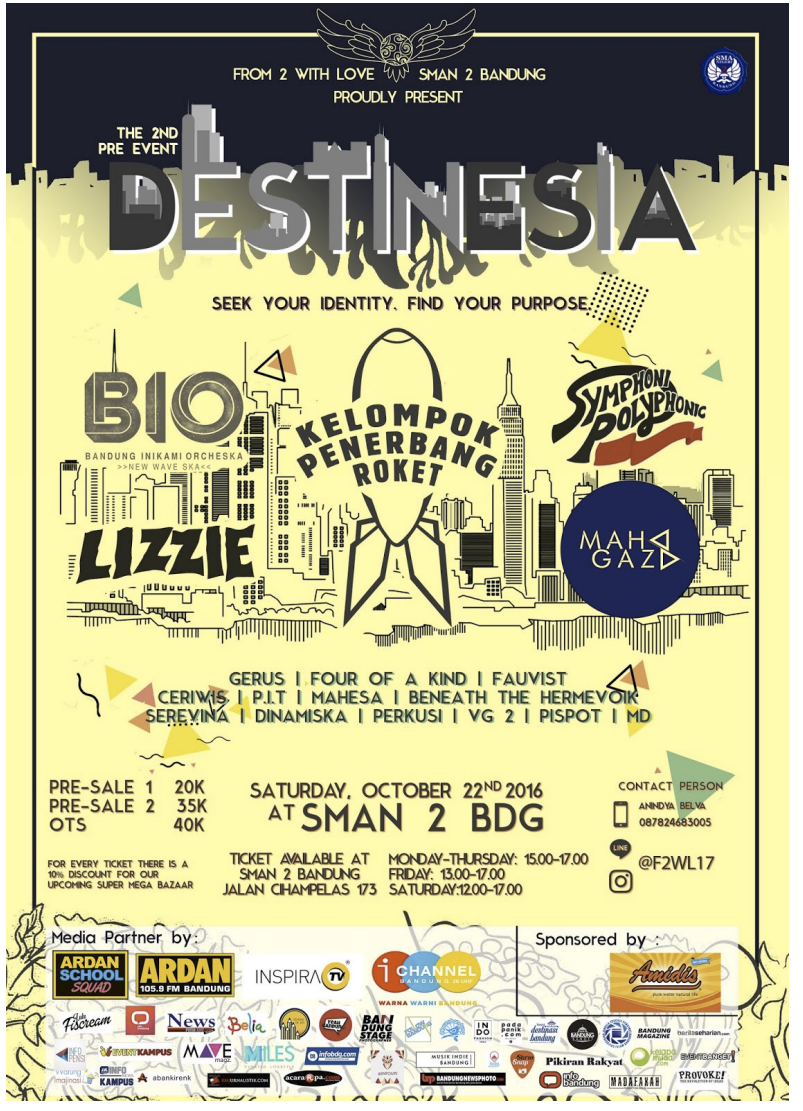

Sumber: Instagram I Channel, 2017

Gambar 4 Media Partner Kegiatan Destinesia

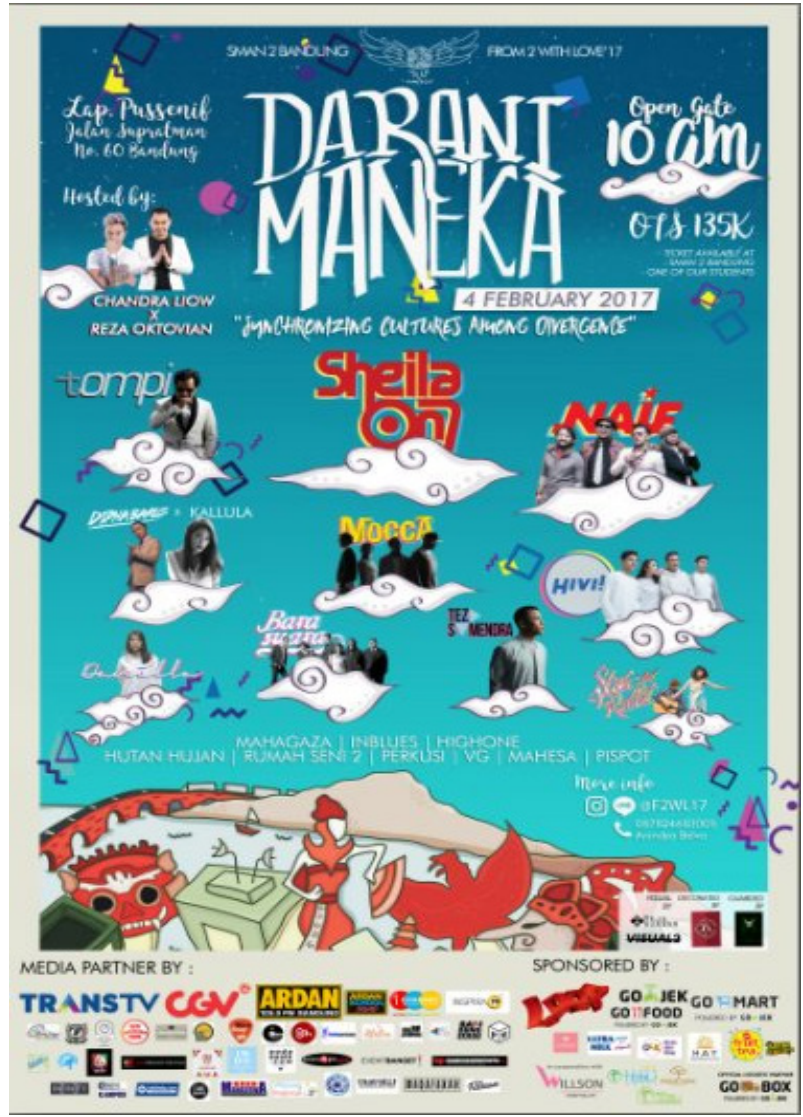

Sumber: Instagram I Channel, 2017

Gambar 5 Media Partner Kegiatan Darani Maneka

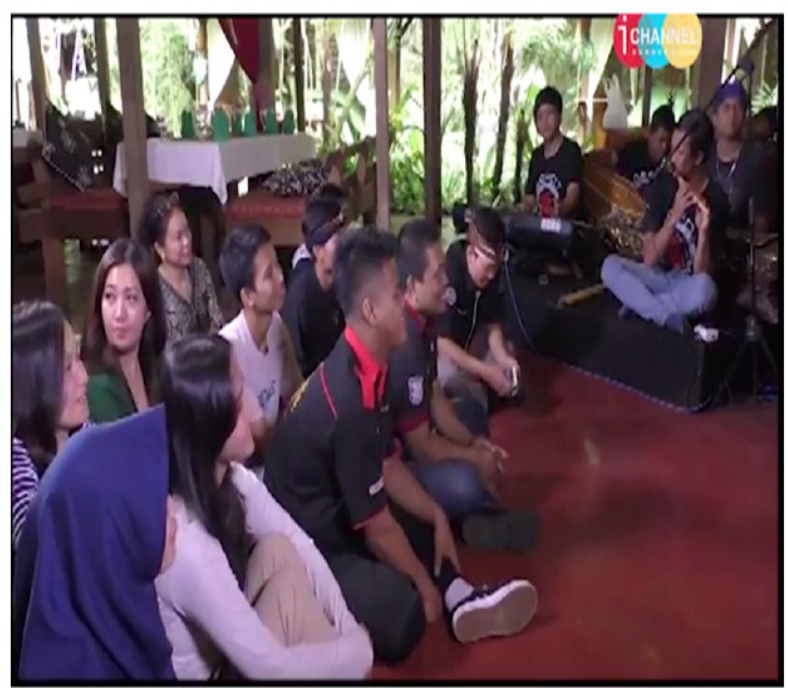

Sumber: Instagram I Channel, 2017

\section{Gambar 6 Nonton Bareng "Sampurasun Cepot" Di Kampung Daun}

strategi pemasaran ini. Namun I Channel Bandung melakukan kegiatan internal saja, yaitu kegiatan mengundang masyarakat 'nonton bareng' acara "Sampurasun Cepot". Kegiatan tersebut dimaksudkan untuk mengikutsertakan masyarakat sebagai penonton dan membangun hubungan baik dan keterikatan (bounding), sekaligus diharapkan dapat meningkatkan kesadaran merek perusahaan. Hal ini ditampilkan melalui gambar 6 .

Melalui penelitian ini ditemukan bahwa I Channel Bandung telah menggunakan komunikasi pemasaran terpadu dalam upaya peningkatan brand awareness di masyarakat atau integrated marketing communication I Channel Bandung melalui budaya lokal. Berikut kegiatan IMC yang telah dilakukan, yaitu sebagai berikut: (1) Melakukan periklanan terkait dengan program acara "Sampurasun Cepot" pada media massa milik sendiri, (2) Menggunakan media internet sebagai sarana beriklan, baik melalui official website dan unofficial website, (3) Melakukan direct email kepada client untuk melakukan penawaran pemasangan iklan di slot program acara "Sampurasun Cepot", (4) Melakukan kegiatan sales promotion baik kepada calon pemasang iklan dengan cara memberi harga promo atau potongan harga, dan kepada masyarakat dengan memberi merchandise hanya kepada lembaga pendidikan sebagai tempat I Channel bermedia partner, (5) Personal selling dilakukan dengan mengutamakan komunikasi antar pribadi antara divisi marketing dan calon pemasang iklan 
serta penonton sekaligus menjaga hubungan baik dengan para client maupun calon client, (6) Kegiatan Public relations yang dilakukan oleh divisi Marketing Komunikasi I Channel ini adalah dengan melakukan publikasi, dan (7) Kegiatan event \& sponsorship belum dilakukan divisi Marketing Komunikasi secara langsung, namun menjadi bagian dari kegiatan promosi dan iklan. Adapun Kendala-kendala yang dihadapi dan menjadi faktor utama divisi Marketing Komunikasi kesulitan melakukan kegiatan IMC dengan maksimal adalah budget perusahaan yang sangat terbatas sehingga elemen kegiatan pemasaran dalam IMC belum maksimal dilaksanakan.

I Channel Bandung melakukan enam elemen Komunikasi Pemasaran Terpadu (IMC) yang mempunyai tingkat keefektifan yang berbeda-beda. Kegiatan direct marketing dan advertising menggunakan media sosial untuk menunjang kegiatan tersebut dan menjadi media utama dalam penyebaran informasi dan persuasi kepada khalayak/masyarakat. Masyarakat dapat mengakses informasi dan berinteraksi lebih mudah satu dengan lainnya. Media sosial yang digunakan oleh I Channel sendiri berupa website, Instagram, Youtube, Twitter, serta email. Dari kelima media sosial yang dimiliki I Channel, berdasarkan hasil obervasi, hanya ada dua media sosial yang berperan penting dalam kegiatan IMC ini, yaitu website dan youtube. Hal ini dikarenakan website I Channel memiliki informasi terlengkap dibandingkan dengan media lain. Selain itu di dalam website ada link khusus ke channel Youtube yang diisi dengan program-program acara I Channel, termasuk program wayang golek "Sampurasun Cepot".

Sedangkan kegiatan sales promotion yang dikemukakan oleh Marketing Komunikasi I Channel, televisi lokal I Channel Bandung belum melaksanakannya karena keterbatasan pembiayaan. Kegiatan sales promotion yang hanya ditujukan kepada para client, dengan memberikan gratis peliputan di awal, pemberian diskon harga penayangan iklan, maupun garansi dalam merevisi tayangan iklan bila client merasa kurang puas atas hasil iklan yang ditayangkan. Namun belum ada kegiatan sales promotion di dalam acara "Sampurasun Cepot" itu sendiri.

Selanjutanya mengenai personal selling yang dilakukan adalah berkomunikasi dengan pemasang iklan mengenai acara "Sampurasun
Cepot" itu sendiri. Program wayang golek satusatunya yang ada di Bandung memberikan kelebihan dan mampu menarik suatu perusahaan untuk memasang iklan di I Channel Bandung. Selain itu kegiatan personal selling dilakukan dalam memberikan informasi seputar acara "Sampurasun Cepot" kepada komunitaskomunitas, seperti komunitas paguyuban Sunda, komunitas mobil, serta komunitas vespa Bandung. Kegiatan ini biasa dilakukan dengan tatap muka, dengan memberi informasi tema terbaru "Sampurasun Cepot" yang akan ditayangkan pada minggu yang sama.

Elemen selanjutnya dalam IMC yakni public relations, yaitu melobi para pemasang iklan, baik dari kalangan perusahaan suatu produk atau jasa, maupun dinas-dinas pemerintahan Kota Bandung. Kegiatan ini digunakan untuk dapat mencapai target perusahaan sebagai sumber pemasukan dan penggerak roda perusahaan. Selain itu divisi Marketing Komunikasi juga melakukan perluasan relasi dengan masuk ke dalam komunitas dengan tujuan pengenalan brand perusahaan. Serta dengan memilih tematema pada acara "Sampurasun Cepot" bersama produser.

Divisi Marketing Komunikasi bekerja sama dengan melakukan media partner dalam rangka membantu kegiatan komunikasi dalam memublikasikan perusahaan. Banyaknya proposal yang masuk dari berbagai perusahaan media yang meminta I Channel Bandung sebagai media partner sangat menggembirakan, karena animo yang besar menunjukkan bahwa peluang publikasi juga semakin banyak publikasi yang dilakukan, dan berdampak positif kepada peningkatan kesadaran masyarakat terhadap program acara "Sampurasun Cepot" khusunya, dan stasiun televisi lokal I Channel Bandung umumnya.

Kegiatan event \& sponsorship belum dilakukan divisi Marketing Komunikasi secara langsung, namun menjadi bagian dari kegiatan promosi dan iklan. Berdasarkan hasil wawancara serta observasi, I Channel tidak melakukan elemen IMC event and sponsorship disebabkan keterbatasan dana yang dimiliki perusahaan.

Divisi Marketing Komunikasi melakukan kegiatan lain yang mendukung hasil maksimal yang memberikan dampak yang positif bagi peningkatan kesadaran merek I Channel Bandung yaitu dengan memaksimalkan 
pemanfaatan media yang ada. Namun Divisi Marketing Komunikasi telah melakukan elemen event bagi program acara "Sampurasun Cepot" di luar studio, tepatnya di restoran Kampung Daun. Restoran ini beriklan melalui acara "Sampurasun Cepot" sehingga proses shooting diadakan di lokasi terebut. Selain itu, Divisi Marketing Komunikasi juga pernah menyelenggarakan nonton bareng (Nobar) masyarakat kota Bandung untuk dapat lebih dekat dengan acara "Sampurasun Cepot".

Berbagai elemen yang digunakan di dalam acara "Sampurasun Cepot" juga menjadi salah satu faktor keberhasilan acara ini dalam meningkatkan brand awareness pada penonton. Pemilihan tema acara dilakukan dengan mengaitkan unsur IMC, sehingga tema ringan yang dibawakan selalu tepat sasaran, karena bertujuan untuk mempromosikan I Channel Bandung yang memiliki slogan warna-warni Bandung. Sehingga pemilihan tema acara selalu dikaitkan dengan suatu kejadian yang sedang ramai dibicarakan atau sedang berlangsung di Bandung.

\section{SIMPULAN}

Dalam upaya meningkatkan brand awareness, I Channel Bandung melakukan proses dan aktivitas Intergrated Marketing Communication (IMC) untuk memenangkan khaayak. Dalam hal itu, Marketing Komunikasi I Channel Bandung menggunakan dua cara, yaitu langsung dan tidak langsung. Komunikasi langsung berupa tatap muka digunakan untuk lebih ditekankan dalam proses peningkatan brand awareness perusahaan. Di mana pada strategi IMC ini selalu diselipkan komunikasi interpersonal agar dapat mencapai tujuan perusahaan. Mulai dari sales promotion, personal selling hingga public relations terfokus kepada komunikasi secara langsung. Hal ini dilakukan oleh Marketing Komunikasi sebagai penguat dalam peningkatan awareness masyarakat kepada I Channel Bandung. Cara kedua yang digunakan adalah komunikasi pemasaran secara tidak langsung yang lebih difokuskan kepada advertising. Di mana Marketing Komunikasi menggunakan media sosial untuk dapat memberi informasi seputar acara "Sampurasun Cepot" serta televisi di mana acara tersebut bernaung.

Penggunaan media sosial menjadi sangat efisien, karena lebih mudah diakses oleh masyarakat serta dapat menjangkau seluruh target sasaran. Hasil yang diperoleh terkait dengan IMC I Channel Bandung dapat dilihat dari bentuk kegiatan yang masih berjalan hingga sekarang. Kekuatan I Channel Bandung ini terletak pada kegiatan personal selling serta public relations jika dikaitkan dengan IMC. Hal ini dapat dilihat bagaimana hubungan antara I Channel Bandung dengan para client. Kurangnya SDM menjadikan kegiatan IMC tidak bias dilakukan secara maksimal. Banyaknya tugas rangkap yang harus dikerjakan oleh satu orang, menghasilkan hasil yang tidak sempurna. Divisi Marketing Komunikasi telah melakukan komunikasi pemasaran terpadu sesuai dengan teori Tuckwell. Walaupun untuk kegiatan event dan sponsorship belum dilakukan, berkenaan dengan budget yang sangat minim dari perusahaan.

Berdasarkan analisis dan kesimpulan, maka terdapat saran mengenai penelitian ini, baik saran teoritis maupun saran praktis, yaitu: (1) Penelitian lanjutan dapat dilakukan dengan menggunakan teori, konsep, pendekatan dan metode penelitian yang berbeda agar memperoleh hasil yang objektif mengenai penggunaan teori komunikasi pemasaran terpadu (Integrated marketing communication) dari Tuckwell dan tahapan brand awareness dari Aaker. Harapannya penelitian dapat menghasilkan hasil pengukuran dari variabelvariabel yang digunakan sehingga analisis interpretatif menjadi lebih bermakna. (2) Saran praktis yang dapat peneliti berikan, sebagai berikut: (a) I Channel Bandung tetap menggunakan kekuatan budaya Sunda sebagai wujud dari tanggung jawab pengembangan kearifan lokal (local wisdom) dalam industri media yang acap kali terabaikan karena dianggap tidak dapat 'menjual atau membangun kesadaran merek, (b) Kegiatan sales promotion lebih difokuskan sehingga memungkinkan pemasangan iklan dapat bertambah. Jika kemasan program dan komunikasi personal dilakukan dengan pemasang iklan, sangat mungkin iklan akan memadai untuk program lokal, (c) Divisi marketing lebih kreatif dengan menggunakan alat-alat komunikasi pemasaran yang ada sekarang harus di tambah dengan alat komunikasi pemasaran lain, seperti booklet, flyer, merchandise. (d) Budget divisi Marketing Komunikasi kreativitas marketing. 
(e) Pihak I Channel memaksimalkan kualitas dan pencapaian kinerja di tengah keterbatasan jumlah Sumber Daya Manusia (SDM).

\section{DAFTAR PUSTAKA}

Aaker, D. A. (1997). Manajemen ekuitas merek. Jakarta: Penerbit Mitra Utama.

Arisandi, D. (2017). Pengaruh humor appeals terhadap brand awareness, pada iklan televisi. Jurnal Ilmiah Manajemen \& Bisnis. Vol. 18 No. 1, 2017, 1-8). Jurnal UMSU - Universitas Muhammadiyah. Diakses dari http://jurnal.umsu.ac.id/index. $\mathrm{php} / \mathrm{mbisnis} /$ issue/view/372

Daymon, C. \& Holloway, I. (2008). Metodemetode riset kualitatif. Bandung: Bentang Pustaka.

Denzin, N. K. \& Lincoln, Y. S. (2009). Handbook of qualitative research. Yogyakarta: Pustaka Pelajar

I Channel Bandung Official Website. (2017). I channel. Diunduh dari http: //I Channeltv. co.id/about-us/\#contact-I Channel diakses pada pukul 2.09 WIB 2 November 2017.

Keke, Y. (2015). Komunikasi Pemasaran terpadu terhadap brand awareness, Jurnal Manajemen Bisnis Transportasi Dan Logistik. Vol.2 No 1, 2015:12). Link : library.stmt-trisakti.ac.id/jurnal/index.php/ JMBTL/article/download/44/pdf_28

Koentjaraningrat. (2000). Kebudayaan mentalitas dan pembangunan (cetakan kesembilan belas). Jakarta: Gramedia Pustaka Utama.

Kotler, P. \& Keller, K. L. (2007). Manajemen pemasaran, Jilid I, Edisi Kedua belas. Jakarta: Indeks.

Kotler, P. \& Keller, K. L. (2008). Manajemen pemasaran jilid 1,edisi ketiga belas, terjemahan bob sabran. Jakarta: Erlangga.

Liliweri, A. (2002). Makna budaya dalam komunikasi antar budaya. Yogjakarta: LKiS Pelangi Aksara.

Mahayuni, P. Y. A., Purnawan, N. L. R., \& Cahyani, D. Y. (2017). Strategi komunikasi pemasaran terpadu pt. Gojek indonesia branch bali dalam pembentukan brand awareness. Jurnal medium. Vol. 1 No. 1 2017. Diakses dari https://ojs.unud.ac.id/ index.php/komunikasi/article/view/26555

Malik, E., Muhammad., Ghafoor, M. M., Iqbal,
H. K., Riaz, U., Hassan, N., Mustafa, M., Shahba, S. (2013) 'Importance of Brand awareness and Brand Loyalty in assessing Purchase Intentions of Consumer'. Jurnal International Journal of Business and Social Science, Vol. 4 No. 5; May 2013: 167. Link: ijbssnet.com/journals/Vol_4 No_5_May_2013/18.pdf. diakses pada Juamt, 6 Juli 2018 Pukul 14.30 WIB.

Morissan, MA. (2005). Media PenyiaranStrategi Mengelola Radio dan Televisi. Jakarta: Ramdina Prakasa.

Oktara, M. Y. (2017). Komunikasi Pemasaran PT. Pindad (Persero) di Asia Tenggara. Jurnal Kajian Komunikasi, Volume 5, No. 2, Desember 2017, hlm. 190-201, diakses, 17 September 2018, Pukul 14.45 WIB.

Peraturan Komisi Penyiaran Indonesia Nomor 01/P/KPI/03 (2012) Tentang, "Pedoman Perilaku Penyiaran dan Standar Program Siaran (P3SPS)".http: //www.kpi.go.id/ download/regulasi/P3SPS_2012_Final.pdf diakses pukul 18.55 WIB 29 Juni 2017.

PPID Bandung. (2017). Daftar stasiun TV lokal. Diakses dari https: //ppid.bandung.go.id/ knowledgebase/daftar-stasiun-tv-lokal/ 23.00 WIB 8 November 2017

PPID KemKominfo. (2014). PP No. 11 Tahun 2005. Diakses dari https://ppidkemkominfo. files.wordpress.com/2014/02/pp_no_11 th 2005.pdf. ]PP No.11 Tahun $200 \overline{5}$ Tentang Penyelenggaraan Penyiaran.

Putra, D. A., \& Idris. (2018). Analisis Kesadaran Merek, Persepsi Kualitas, Asosiasi Merek, dan Loyalitas Merek Yang Mempengaruhi Ekuitas Merek Produk Sepatu Olahraga Merek Adidas (Studi Kasus Pada Masyarakat di Kota Semarang) eprints.undip.ac.id/34961/1/...PUTRA (C2A007031)_JURNAL.pdf, diakses 21 Februari 2018 Pukul 10.06 WIB

Rangkuti, F. (2004). The power of brand. Jakarta: Gramedia Pustaka Utama.

Romaniuk, J., Wight, S., \& Faulkner, M. (2016). 'Brand awareness: revisiting an metric for a new'... - Emerald Insight. Link : https:// www.emeraldinsight.com/doi/10.../JPBM06-2016-12. Diakses pada Jumat, 06 Juli 2018 Pukul 14.45 WIB.

Shimp, T. A. (2003). Periklanan promosi aspek tambahan. komunikasi pemasaran terpadu. Terjemahan oleh: Revyani Sjahrial, S.E. 
dan Dyah Anikasari, Jakarta: Erlangga.

Sopanah. (2012). Ceremonial Budgeting Dalam

Perencanaan Penganggaran Daerah: Sebuah

Keindahan Yang Menipu. Banjarmasin: Simposium Nasional Akuntansi (SNA) 15.

Tuckwell, K. J. (2008). Integrated marketing communication: strategic planning perspective. Second Edition. USA: Pearso Pretice Hall.

Undang-Undang Republik Indonesia No. 32

Tahun 2002 Tentang Penyiaran. 2002.

Lembaga Penyiaran Publik. Bagian
Kesepuluh Rencana Dasar Tehnik Penyiaran dan Persyaratan Teknis Perangkat Penyiaran Pasal 32: Hal 13-14

Wahid, U. \& Anggun, E. P. (2017). Upaya peningkatkan brand awareness pt. gojek indonesia melalui aktivitas marketing public relations. Universitas Budi Luhur: Jurnal Komunikasi, Vol. 9 No. 1 World, Jurnal Simbolika/Volume 2/Nomor 1/ Maret 2016. Link:jurnalsimbolika.files. wordpress.com/2016/12/. Diakses pada 21 Februari 2018 Pukul 11.13 WIB. 